\title{
Impacts of Anthropogenic Stressors on Hydrochemistry, Benthic Macroinvertebrates and Sediment Characteristics of the Lagos Lagoon, Nigeria
}

\author{
${ }^{1}$ FASUYI, OF; ${ }^{2}$ YUSUF, WA; $* 1$ NKWOJI, JA \\ ${ }^{* 1}$ Benthic Ecology, Department of Marine Sciences, University of Lagos, Lagos \\ ${ }^{2}$ Fisheries Resources Department, Nigerian Institute for Oceanography and Marine Research, Lagos \\ *Corresponding Author Email: jnkwoji@ unilag.edu.ng
}

\begin{abstract}
The anthropogenic impact on the water, benthic macroinvertebrates and sediment grain size of Lagos lagoon was investigated between July and October, 2019. Ten sampling stations were selected based on their importance as likely sources of different forms of anthropogenic stressor to the lagoon. Water temperatures, $\mathrm{pH}$ and salinity were measured in situ. Water and benthic samples were collected monthly and analysed using standard methods. Nutrient levels were determined using a spectrophotometer. The hydrochemistry of the stations differed significantly $(\mathrm{p}<0.05)$ with the exception of temperature and $\mathrm{pH}$. The sediment grains across the study stations consists basically of sand and mud, with sand dominating the grain type. A total of 502 individuals comprising 3 phyla, 4 classes, 10 families and 11 species was recorded. The phylum mollusca which contributed $92 \%$ to the total number of individuals was represented by two Classes; Gastropoda and Bivalvia, with the gastropod Tympanotonus fuscatus having the highest number of individuals (321). The phylum Annelida represented by one Class, Polychaeta and two Species Nereis sp. and Capitella capitata contributed 6\% to the total number of individuals. The class Crustacea, representing the Phylum Arthropoda was the least sampled (7 individuals) constituting about $1.4 \%$ of the total population Result showed that different pollution sources have negatively impacted the water chemistry of the lagoon and reduced the diversity and abundance of its benthic macroinvertebrates community. The sedentary nature of this group of benthic fauna could be the major reason why they are most impacted.
\end{abstract}

\section{DOI: https://dx.doi.org/10.4314/jasem.v25i8.10}

Copyright: Copyright $\odot 2021$ Fasuyi et al. This is an open access article distributed under the Creative Commons Attribution License (CCL), which permits unrestricted use, distribution, and reproduction in any medium, provided the original work is properly cited.

Dates: Received: 10 May 2021; Revised: 28 June 2021; Accepted: 01 July 2021

Keywords: Benthic macroinvertebrates; Biomonitoring; Bioindicators; Anthropogenic

Lagoons serve as ecotones between freshwater, marine and terrestrial biotopes (Saki-Yao et al., 2017) and hence, are heavily impacted (Kennish, 2002). Heightened anthropogenic activities increase the influx of stressors into the lagoons (Christensen et al., 2006, Halpern et al. 2007, Crain et al., 2008) leading to declines in biodiversity and significant distortion of the ecosystems function (Bulling et al., 2010). Macroinvertebrates are impacted by pollutants primarily as a result of changes in primary production and in the chemistry of water column and sediment. These changes potentially lead to reduced diversity and abundance, shifts in community composition, physiological changes and mass mortality. Several authors have published quite a number of research articles on the Lagos lagoon due to its inexhaustible importance and location. Ajao and Fagade, (1991) studied of the sediments and communities in Lagos Lagoon. The study focused more on the role of sediment composition and type in the structure of the benthic communities. Nkwoji et al. (2010) worked on the benthic macroinvertebrates Bioindicators at the Lagos lagoon and emphasized on the importance of pollution sensitive macroinvertebrates on the health of the coastal lagoon. Edokpayi and Nkwoji (2007) also recorded a relatively high number of polychaete worms at the sewage dump site of the Lagos lagoon. Olapoju and Edokpayi (2018) carried out a study on the water quality and sediment quality of the Lagos Lagoon. The aim of this research is to determine the impacts of anthropogenic stressors on hydrochemistry, benthic macroinvertebrates and sediment characteristics of the Lagos Lagoon.

\section{MATERIALS AND METHODS}

Study area: The Lagos lagoon (Fig. 1) located between longitudes $3^{\circ} 23^{\prime}$ and $3^{\circ} 40^{\prime} \mathrm{E}$, and latitudes $6^{\circ} 26^{\prime}$ and $6^{\circ} 38^{\prime} \mathrm{N}$, is the largest lagoon system in the West African coast, covering $208 \mathrm{~km}^{2}$. It has a total surface area of approximately $6,354.7 \mathrm{~km}^{2}$. Ten sampling stations were selected for this study based on their importance as sources of different forms of anthropogenic stressor to the Lagos lagoon. The Global Positioning System (GPS) was used to ascertain coordinates of the sampling points. 


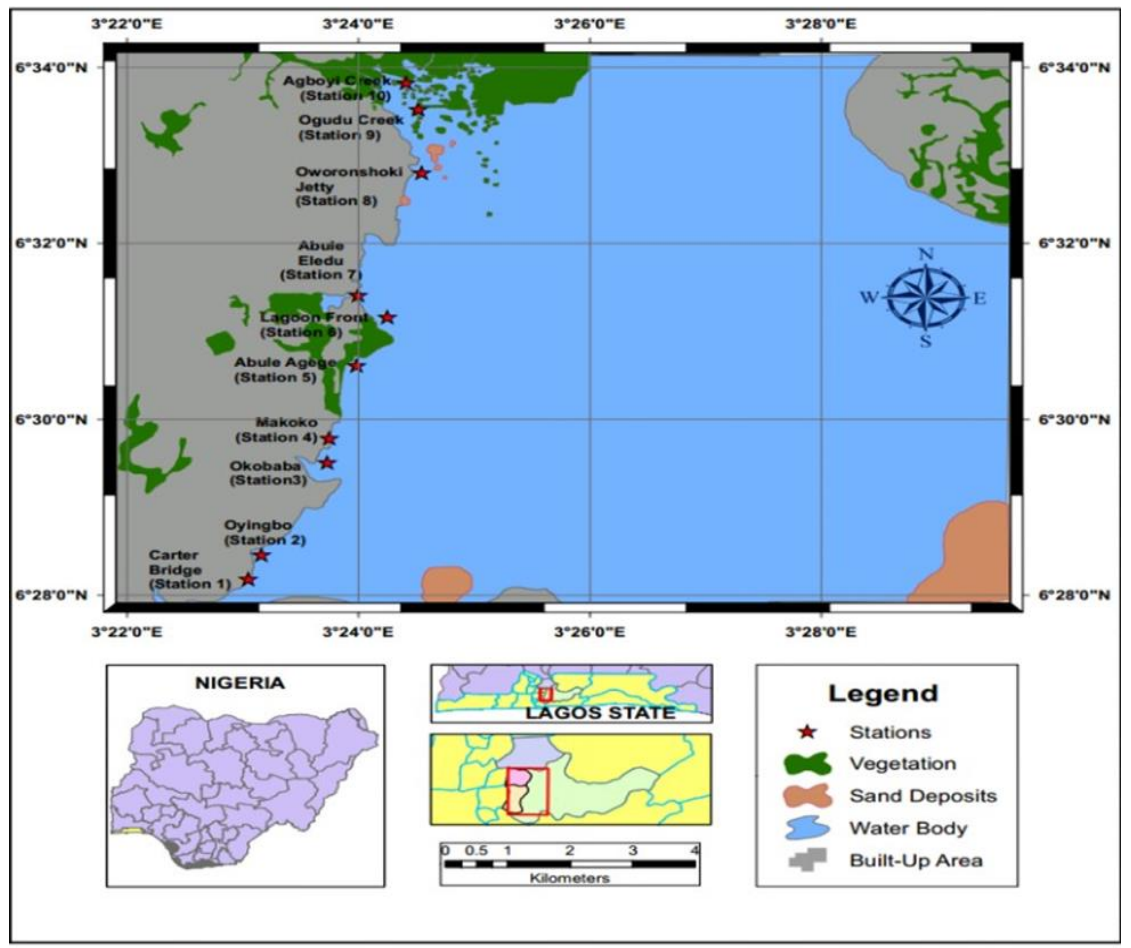

Fig 1: Map of the Lagos Lagoon Showing Sampling Stations

Collection and Analysis of Water samples: Water temperatures, $\mathrm{pH}$ and salinity were measured in situ at every sampling station with mercury in glass thermometer, Hach Picket $\mathrm{pH}$ Meter and Horiba water checker (Model U-10) respectively. Subsurface water samples were collected with $1 \mathrm{dm}^{3}$ Hydrobios water sampler and stored in a pre-labelled plastic containers following the methods described by APHA (2002). The dissolved oxygen (DO) and biological oxygen demand (BOD) of the water samples were determined using Winkler's technique. The total suspended solids were determined using gravimetric methods while the total dissolved solids and conductivity were measured using a HACH conductivity/Salinity/TDS meter (Model, CO150), while nutrient levels were determined and using a spectrophotometer.

Collection and Analysis of Benthic Samples: Benthic samples were collected with the use of $0.1 \mathrm{~m}^{2}$ VanVeen grab. Part of the benthic samples were kept in a polyethene bag and preserved for further analysis on the sediment grain size. The remaining benthic samples were sieved through $0.5 \mathrm{~mm}$ mesh size sieve. The materials retained on the sieve were stored in labelled plastic container and preserved in $10 \%$ formalin for further analysis in the laboratory. Sorting of the benthic samples was done with the aid of a handheld magnifying lens to obtain the clean samples of the benthic macro fauna.
Statistical Analysis: The statistical package for social sciences (SPSS) was used to calculate the Analysis of Variance (ANOVA) for all the physicochemical parameters while Microsoft Excel was employed for the descriptive statistics of the data. Data processing of the benthic macro invertebrates involved the calculation of biological indices such as Margalef's index for Species richness, Shannon-Wiener and Simpson's indices for species diversity, and the Equitability index for evenness of the community (Ogbeibu, 2005). Margalef's Species Richness Index (d): The Species richness index (d) was calculated using the Margalef's index and used to evaluate the community structure. The equation below was applied and results were recorded to two decimal places.

$d=\frac{S-1}{\ln N}$

Where: $d=$ Species richness index; $S=$ Number of species in a population; $\mathrm{N}=$ Total number of individuals in $\mathrm{S}$ species.

Shannon and Wiener Diversity Index $(H)$ : Shannon and Weiner diversity index $(\mathrm{H})$ is given by the equation:

$$
H^{\prime}=\sum_{i=1}^{s}\left(p_{i}\right)\left(\ln p_{i}\right)
$$


Where: $\mathrm{H}^{\prime}=$ Diversity Index; $\mathrm{i}=$ Counts denoting the ith species ranging from $\mathrm{i}-\mathrm{n} ; \mathrm{Pi}=$ Proportion that the ith species represents in terms of numbers of individuals with respect to the total number of individuals in the sampling space as whole.

Species Equitability (j) or Evenness Index: Species evenness or equitability was used to calculate how evenly the species are distributed in a community. It was determined by the equation:

$J=\frac{H s}{\log 2 S}$

Where: $\mathbf{J}=$ Equitability index; Hs = Shannon and Weiner index; $\mathrm{S}=$ Number of species in a population

Simpson's Dominance Index (Ogbeibu, 2005)

$$
\mathrm{C}=\sum\left[\frac{\mathrm{n}}{\mathrm{N}}\right]^{2}
$$

Where: $\mathrm{n}=$ the total number of organisms of a particular species; $\mathrm{N}=$ the total number of organisms of all species.

\section{RESULTS AND DISCUSSIONS}

The low water temperatures across the months and sample stations may be due to the effect of high insulation and the dilution effects of flood waters. The slight variation in the values of water temperature (27.25- $27.88^{\circ} \mathrm{C}$ ) may be linked to regular tidal motions, which ensured the complete mixing of the water. There was no significant difference in the water temperature $(p>0.05)$ across the study stations in consonance with previous works which confirms that temperature is a conservative factor in most tropical waters. The values are within desirable limits for aquatic normal life. The mean hydrogen ion index $(\mathrm{pH})$ values across the study stations showed very little variations. It ranged between 6.25 and 6.73 during the period of study, hence slightly acidic. There was no significant $(P<0.05)$ difference in the $\mathrm{pH}$ values at the study stations as this was in harmony with earlier works of Nkwoji (2017). The wide salinity variation $(p<0.05)$ recorded across the study stations reflects tidal influences on the salinity of the study stations on the premise of their closeness to the sea and introduction of freshwater through run-offs and precipitation causing a dilution effect on the Lagoon. The highest salinity value $(14.43 \%)$ recorded at Carter Bridge could be as a result of their proximity to the Lagos Harbour. Analysis of Variance showed significant difference $(\mathrm{P}<0.05)$ in Dissolved Oxygen among the study stations. This observed increase in dissolved oxygen during the period of study could be as a result of increased aeration because of rainfall (Adeyemo et al., 2008). Ayoade et al. (2006) reported that D.O concentration at Asejire Lake reached its peak at the height of rainy season. Onyema et al (2009) had attributed high level of dissolved oxygen to the perturbation of water and this was prevalent in the wet season. The highest TSS value recorded in Ogudu $(92.95 \mathrm{mg} / \mathrm{L})$ could be attributed to the land-based sources of industrial and domestic wastes from drainages that flow into the lagoon through the adjourning creeks. This observation is in harmony with earlier works on the Lagos lagoon (Okoye et al 2010; Nkwoji and Edokpayi, 2013). This study recorded relatively high values of total dissolved solids across the stations. The TDS values ranged between $3830 \mathrm{mg} / \mathrm{L}$ and $18,010 \mathrm{mg} / \mathrm{L}$. High values were observed in Carter Bridge (Station 1), Oyingbo (Station 2) and Okobaba (Station 3). Carter Bridge recorded the highest value of TDS. This could be as a result of wood wastes washed down this this study station. These stations are heavily impacted by several anthropogenic stressors ranging from illegal oil bunkering resulting in spillage of oils and washing of cement bags at Carter Bridge to wood-logging and wood exudates at Okobaba. These activities would have impacted on the water quality of the study area. The Analysis of the sediment of the study area revealed that the sediment grains consists basically of sand and mud. The mean spatial variation in sediment grain size is presented in Figure 2 and indicates the sediment from all stations was dominated by sand, except for Carter bridge (Station 1), Abule Eledu (Station 7) and Ogudu (Station 9) sampling stations. Carter Bridge (Station 1) recorded an equal percentage of mud and sand in its sediment composition during the period of study. The study stations that had higher percentage of sediment composition as mud are Ogudu (Station 9) and Abule Eledu (Station 7). These stations have intense dredging and sediment mining activities going on, which has made them relatively deeper than other stations. The subsequent siltation would lead to accumulation of mud. A total of 502 individuals comprising 3 phyla, 4 Classes, 10 Families and 11 Species was recorded. The Phylum Mollusca was represented by two Classes; Gastropoda and Bivalvia. Gastropoda, represented by 4 Families and 5 Species recorded the highest number of individuals (374) accounting for $74.5 \%$ of the total number of individuals sampled for the period of study while the Class Crustacea, representing the Phylum Arthropoda were the least sampled (7 individuals) constituting about $1.4 \%$ of the total population. Only one species Clibanarius africanus was recorded from this phylum throughout the period of study. 


\begin{tabular}{|c|c|c|c|c|c|c|c|c|c|c|c|c|}
\hline PARAMETERS & $\begin{array}{l}\text { Water } \\
\text { Temp. }{ }^{\circ} \mathrm{C}\end{array}$ & $\begin{array}{l}\text { pH @ } 25 \\
{ }^{\circ} \mathbf{C} \\
\end{array}$ & Salinity $\left(\%_{0}\right)$ & $\begin{array}{l}\mathrm{DO} \\
(\mathrm{mg} / \mathrm{L})\end{array}$ & $\begin{array}{l}\text { TSS } \\
(\mathrm{mg} / \mathrm{L})\end{array}$ & $\begin{array}{l}\text { TDS } \\
(\mathrm{mg} / \mathrm{L})\end{array}$ & $\begin{array}{l}\text { BOD } \\
(\mathrm{mg} / \mathrm{L})\end{array}$ & $\begin{array}{l}\text { TOC } \\
(\mathrm{mg} / \mathrm{L})\end{array}$ & $\begin{array}{l}\text { Turb. } \\
\text { (mg/L) }\end{array}$ & $\begin{array}{l}\text { Nitrates } \\
(\mathbf{m g} / \mathbf{L})\end{array}$ & $\begin{array}{l}\text { Phosph. } \\
\text { (mg/L) }\end{array}$ & $\begin{array}{l}\text { Sulphates } \\
(\mathrm{mg} / \mathrm{L})\end{array}$ \\
\hline \multicolumn{13}{|l|}{ STATION 1} \\
\hline \multicolumn{13}{|l|}{ Carter Bridge } \\
\hline Min & 26.50 & 6.60 & 9.60 & 4.00 & 31.50 & 17510.00 & 2.80 & 4.05 & 29.00 & 2.10 & 0.52 & 420.00 \\
\hline Max & 28.50 & 6.70 & 18.90 & 4.90 & 43.50 & 18510.00 & 5.90 & 4.56 & 39.70 & 2.50 & 0.75 & 452.00 \\
\hline \multirow[t]{2}{*}{ Mean \pm SD } & $27.25 \pm$ & $6.65 \pm 0.06$ & $14.43 \pm$ & $4.45 \pm$ & $37.5 \pm$ & $18010.00 \pm$ & $3.88 \pm$ & $4.30 \pm$ & $34.53 \pm$ & $2.28 \pm$ & $0.64 \pm$ & $433.50 \pm$ \\
\hline & 0.65 & & 5.01 & 0.47 & 5.89 & 577.35 & 1.44 & 0.29 & 5.93 & 0.17 & 0.12 & 13.40 \\
\hline \multicolumn{13}{|l|}{ STATION 2} \\
\hline \multicolumn{13}{|l|}{ Onyingbo } \\
\hline Min. & 27.00 & 6.50 & 9.20 & 3.70 & 47.50 & 15221.00 & 6.50 & 4.80 & 26.20 & 2.80 & 0.55 & 320.00 \\
\hline Max. & 28.50 & 6.60 & 16.20 & 4.78 & 55.50 & 18221.00 & 10.10 & 4.98 & 37.20 & 3.70 & 0.75 & 360.00 \\
\hline \multirow{2}{*}{ Mean \pm SD } & $27.75 \pm$ & $6.53 \pm 0.50$ & $11.25 \pm$ & $4.45 \pm$ & $51.00 \pm$ & $16096.00 \pm$ & $7.88 \pm$ & $4.89 \pm$ & $31.90 \pm$ & $3.23 \pm$ & $0.63 \pm$ & $334.00 \pm$ \\
\hline & 0.65 & & 3.33 & 0.50 & 3.31 & 1436.14 & 1.64 & 0.75 & 6.01 & 0.38 & 0.10 & 17.81 \\
\hline \multicolumn{13}{|l|}{ STATION 3} \\
\hline \multicolumn{13}{|l|}{ Okobaba } \\
\hline Min & 27.00 & 6.60 & 8.30 & 4.10 & 70.20 & 11230.00 & 4.98 & 5.15 & 28.60 & 2.40 & 0.70 & 130.00 \\
\hline Max & 28.00 & 6.80 & 11.30 & 5.10 & 85.20 & 12230.00 & 8.98 & 8.15 & 40.60 & 3.80 & 0.98 & 160.00 \\
\hline \multirow{2}{*}{ Mean \pm SD } & $27.50 \pm$ & $6.73 \pm 0.96$ & $10.05 \pm$ & $4.58 \pm$ & $75.00 \pm$ & $11555.00 \pm$ & $6.73 \pm$ & $6.65 \pm$ & $34.10 \pm$ & $3.05 \pm$ & $0.81 \pm$ & $145.00 \pm$ \\
\hline & 0.41 & & 1.50 & 0.55 & 6.95 & 471.70 & 2.06 & 1.73 & 5.51 & 0.60 & 0.12 & 12.91 \\
\hline \multicolumn{13}{|l|}{ STATION 4} \\
\hline \multicolumn{13}{|l|}{ Makoko } \\
\hline Min & 26.50 & 6.50 & 8.00 & 4.10 & 60.50 & 8720.00 & 5.00 & 2.92 & 27.20 & 3.00 & 1.65 & 210.00 \\
\hline Max & 28.50 & 6.70 & 9.00 & 4.90 & 68.50 & 8920.00 & 10.22 & 7.94 & 38.20 & 3.80 & 1.79 & 310.00 \\
\hline \multirow{2}{*}{ Mean \pm SD } & $27.50 \pm$ & $6.65 \pm 0.10$ & $8.30 \pm$ & $4.53 \pm$ & $64.30 \pm$ & $8820.00 \pm$ & $7.36 \pm$ & $5.44 \pm$ & $32.70 \pm$ & $3.38 \pm$ & $1.73 \pm$ & $260.00 \pm$ \\
\hline & 0.91 & & 0.48 & 0.35 & 3.50 & 81.65 & 2.76 & 2.89 & 5.80 & 0.35 & 0.07 & 52.28 \\
\hline \multirow{2}{*}{\multicolumn{13}{|c|}{$\begin{array}{l}\text { STATION } 5 \\
\text { Abule Eledu }\end{array}$}} \\
\hline & & & & & & & & & & & & \\
\hline Min & 27.00 & 6.50 & 5.00 & 5.10 & 10.30 & 4750.00 & 2.60 & 2.00 & 30.30 & 4.30 & 0.30 & 222.00 \\
\hline Max & 28.50 & 6.60 & 5.10 & 5.60 & 21.30 & 4950.00 & 5.80 & 3.10 & 39.30 & 4.90 & 0.52 & 282.00 \\
\hline \multirow[t]{2}{*}{ Mean \pm SD } & $27.75 \pm$ & $6.55 \pm 0.06$ & $5.03 \pm$ & $5.38 \pm$ & $15.75 \pm$ & $4825.00 \pm$ & $4.65 \pm$ & $2.53 \pm$ & $35.23 \pm$ & $4.55 \pm$ & $0.39 \pm$ & $255.00 \pm$ \\
\hline & 0.65 & & 0.50 & 0.26 & 5.75 & 95.74 & 1.46 & 0.61 & 4.61 & 0.30 & 0.10 & 27.54 \\
\hline \multirow{2}{*}{\multicolumn{13}{|c|}{$\begin{array}{l}\text { STATION } 6 \\
\text { Lagoon Front }\end{array}$}} \\
\hline & \multicolumn{12}{|c|}{ Lagoon Front } \\
\hline Min & 26.5 & 6.50 & 5.10 & 5.00 & 22.10 & 4490.00 & 3.70 & 2.00 & 31.50 & 4.70 & 0.53 & 202.00 \\
\hline Max & 28.5 & 6.60 & 6.10 & 5.20 & 42.30 & 4790.00 & 5.93 & 3.35 & 38.50 & 5.80 & 0.86 & 282.00 \\
\hline \multirow[t]{2}{*}{ Mean \pm SD } & $27.75 \pm$ & $6.58 \pm 0.05$ & $5.38 \pm$ & $5.08 \pm$ & $31.75 \pm$ & $4590.00 \pm$ & $4.81 \pm$ & $2.89 \pm$ & $34.75 \pm$ & $5.23 \pm$ & $0.69 \pm$ & $245.00 \pm$ \\
\hline & 0.87 & & 0.49 & 0.98 & 11.06 & 141.42 & 1.17 & 0.63 & 2.99 & 0.45 & 0.17 & 35.00 \\
\hline \multicolumn{13}{|l|}{ STATION 7} \\
\hline \multicolumn{13}{|l|}{ Abule Agege } \\
\hline Min & 26.50 & 6.30 & 3.80 & 5.20 & 24.80 & 4122.00 & 7.35 & 3.10 & 35.90 & 7.00 & 0.51 & 225.00 \\
\hline Max & 29.00 & 6.80 & 5.80 & 6.30 & 45.80 & 4822.00 & 10.75 & 4.12 & 48.90 & 8.70 & 0.69 & 275.00 \\
\hline Mean \pm SD & $27.88 \pm$ & $6.48 \pm 0.22$ & $4.55 \pm$ & $5.68 \pm$ & $35.40 \pm$ & $4314.00 \pm$ & $8.65 \pm$ & $3.63 \pm$ & $42.68 \pm$ & $8.03 \pm$ & $0.61 \pm$ & $252.00 \pm$ \\
\hline & 1.03 & & 0.96 & 0.52 & 11.67 & 339.94 & 1.52 & 0.56 & 6.26 & 0.72 & 0.08 & 25.74 \\
\hline STATION 8. & & & & & & & & & & & & \\
\hline Oworonshoki & & & & & & & & & & & & \\
\hline Min & 26.50 & 6.40 & 3.00 & 5.10 & 40.40 & 4589.00 & 8.00 & 3.50 & 46.80 & 6.40 & 0.72 & 245.00 \\
\hline Max & 28.00 & 6.70 & 4.80 & 6.10 & 61.40 & 5589.00 & 19.00 & 4.98 & 57.80 & 8.00 & 0.85 & 305.00 \\
\hline
\end{tabular}




\begin{tabular}{|c|c|c|c|c|c|c|c|c|c|c|c|c|}
\hline Mean \pm SD & $\begin{array}{l}27.6 \pm \\
0.75\end{array}$ & $6.53 \pm 0.13$ & $\begin{array}{l}3.70 \pm \\
0.81\end{array}$ & $\begin{array}{l}5.58 \pm \\
0.55\end{array}$ & $\begin{array}{l}50.85 \pm \\
11.51\end{array}$ & $\begin{array}{l}4889.00 \pm \\
476.10\end{array}$ & $\begin{array}{l}11.50 \pm \\
5.07\end{array}$ & $\begin{array}{l}4.32 \pm \\
0.74\end{array}$ & $\begin{array}{l}52.10 \pm \\
5.61\end{array}$ & $\begin{array}{l}7.28 \pm \\
0.72\end{array}$ & $\begin{array}{l}0.78 \pm \\
0.06\end{array}$ & $\begin{array}{l}277.00 \pm \\
31.45\end{array}$ \\
\hline \multicolumn{13}{|l|}{ STATION 9} \\
\hline Min & 26.00 & 5.60 & 1.40 & 4.20 & 86.70 & 3030.00 & 15.23 & 6.34 & 58.80 & 9.00 & 1.60 & 303.00 \\
\hline Max & 28.50 & 6.60 & 3.10 & 5.60 & 98.70 & 6030.00 & 35.25 & 8.72 & 63.80 & 9.90 & 1.85 & 365.00 \\
\hline Mean \pm SD & $\begin{array}{l}27.50 \pm \\
1.08\end{array}$ & $6.25 \pm 0.45$ & $\begin{array}{l}2.03 \pm \\
0.78\end{array}$ & $\begin{array}{l}4.75 \pm \\
0.60\end{array}$ & $\begin{array}{l}92.95 \pm \\
6.13\end{array}$ & $\begin{array}{l}3830.00 \pm \\
1469.69\end{array}$ & $\begin{array}{l}24.49 \pm \\
9.37\end{array}$ & $\begin{array}{l}7.48 \pm \\
1.05\end{array}$ & $\begin{array}{l}61.28 \pm \\
2.36\end{array}$ & $\begin{array}{l}9.40 \pm \\
0.39\end{array}$ & $\begin{array}{l}1.74 \pm \\
0.12\end{array}$ & $\begin{array}{l}333.25 \pm \\
31.29\end{array}$ \\
\hline $\begin{array}{l}\text { STATION } 1 \\
\text { Agboyi }\end{array}$ & & & & & & & & & & & & \\
\hline Min & 27.00 & 5.70 & 1.00 & 4.00 & 85.20 & 3899.00 & 14.50 & 6.50 & 59.10 & 7.80 & 1.50 & 317.00 \\
\hline Max & 28.50 & 6.70 & 2.70 & 4.80 & 89.20 & 4999.00 & 34.65 & 7.95 & 66.50 & 9.50 & 1.72 & 398.00 \\
\hline Mean \pm SD & $\begin{array}{l}27.68 \pm \\
0.70\end{array}$ & $6.30 \pm 0.43$ & $\begin{array}{l}1.75 \pm \\
0.79\end{array}$ & $\begin{array}{l}4.30 \pm \\
0.35\end{array}$ & $\begin{array}{l}87.15 \pm \\
1.64\end{array}$ & $\begin{array}{l}4424.00 \pm \\
607.59\end{array}$ & $\begin{array}{l}22.59 \pm \\
9.50\end{array}$ & $\begin{array}{l}7.11 \pm \\
0.73\end{array}$ & $\begin{array}{l}62.53 \pm \\
3.78\end{array}$ & $\begin{array}{l}8.83 \pm \\
0.72\end{array}$ & $\begin{array}{l}1.57 \pm \\
0.10\end{array}$ & $\begin{array}{l}353.50 \pm \\
40.70\end{array}$ \\
\hline
\end{tabular}

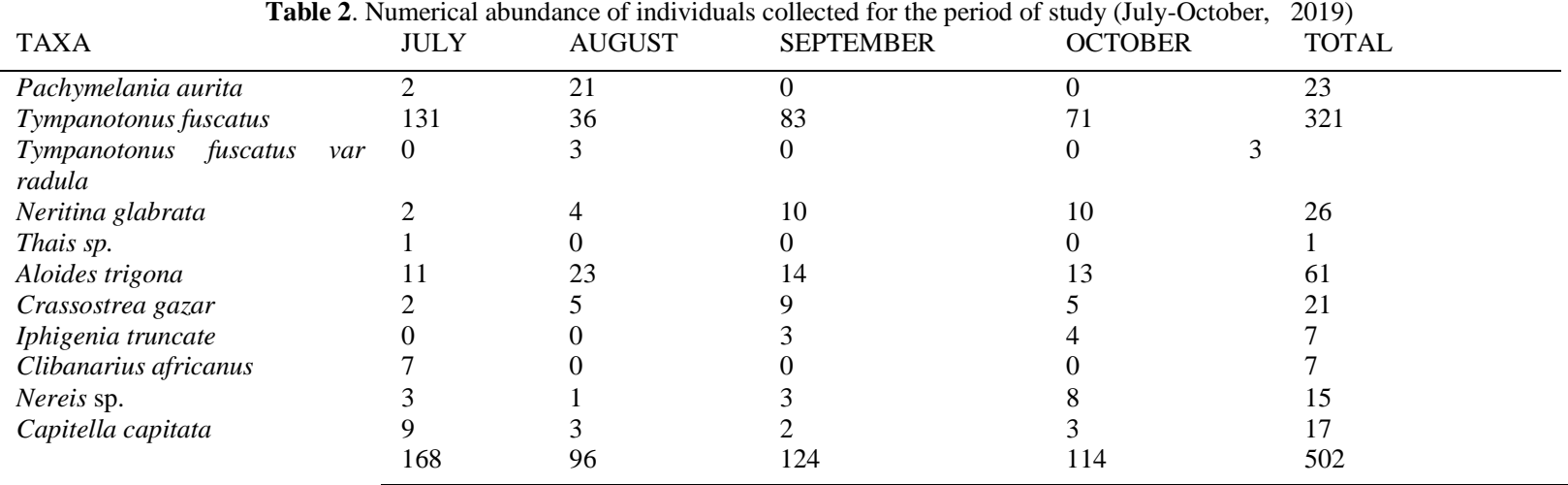

\begin{tabular}{|c|c|c|c|c|c|c|c|c|c|c|}
\hline STATIONS & $\begin{array}{l}\text { Carter } \\
\text { bridge }\end{array}$ & Onyingbo & Okobaba & Makoko & $\begin{array}{l}\text { Abule } \\
\text { Agege }\end{array}$ & $\begin{array}{l}\text { Lagoon } \\
\text { Front } \\
\end{array}$ & $\begin{array}{l}\text { Abule } \\
\text { Eledu }\end{array}$ & Oworonshoki & Ogudu & Agboyi \\
\hline Taxa_S & 3.00 & 2.00 & 5.00 & 3.00 & 5.00 & 7.00 & 3.00 & 2.00 & 3.00 & 3.00 \\
\hline Individuals & 17.00 & 10.00 & 56.00 & 18.00 & 111.00 & 174.00 & 51.00 & 34.00 & 16.00 & 15.00 \\
\hline Dominance_D & 0.35 & 0.52 & 0.59 & 0.35 & 0.60 & 0.43 & 0.62 & 0.56 & 0.45 & 0.50 \\
\hline Simpson_1-D & 0.65 & 0.48 & 0.41 & 0.65 & 0.40 & 0.57 & 0.38 & 0.44 & 0.55 & 0.50 \\
\hline Shannon_H & 1.07 & 0.67 & 0.81 & 1.07 & 0.84 & 1.21 & 0.65 & 0.63 & 0.88 & 0.86 \\
\hline Evenness_e ${ }^{\wedge} \mathrm{H} / \mathrm{S}$ & 0.98 & 0.98 & 0.45 & 0.97 & 0.46 & 0.48 & 0.64 & 0.94 & 0.80 & 0.79 \\
\hline Menhinick & 0.73 & 0.63 & 0.67 & 0.71 & 0.47 & 0.53 & 0.42 & 0.34 & 0.75 & 0.77 \\
\hline Margalef & 0.71 & 0.43 & 0.99 & 0.69 & 0.85 & 1.16 & 0.51 & 0.28 & 0.72 & 0.74 \\
\hline Equitability_J & 0.98 & 0.97 & 0.50 & 0.97 & 0.52 & 0.62 & 0.59 & 0.91 & 0.80 & 0.78 \\
\hline
\end{tabular}




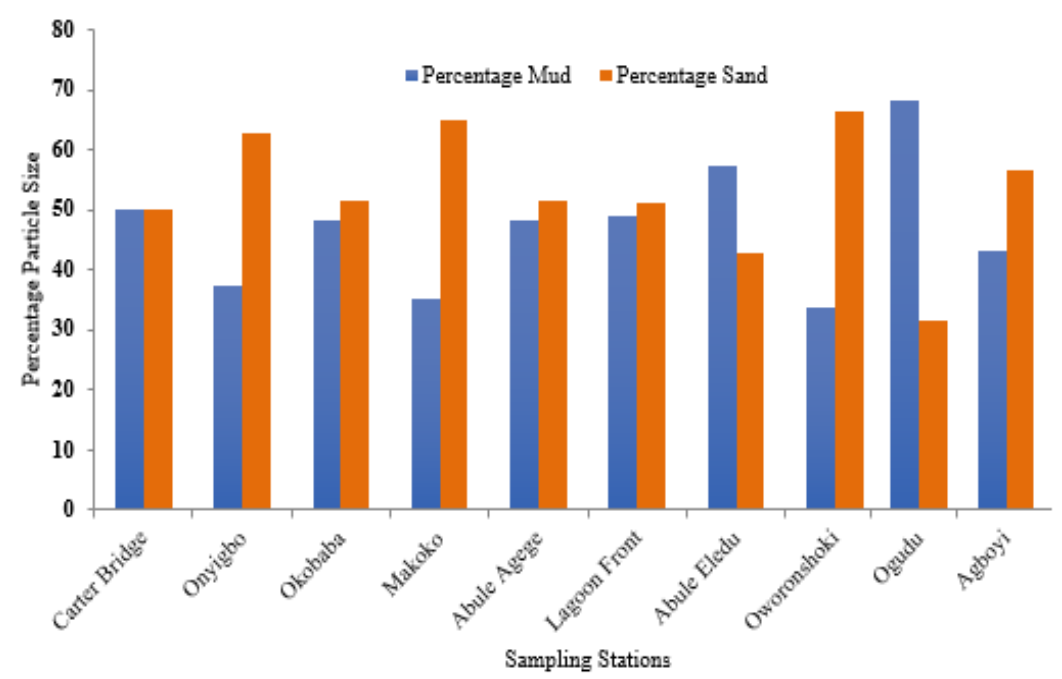

Fig 2. Mean Percentage Composition of sediment particle size during the period of study

Of the ten stations only Station 6 (Lagoon front) recorded clibanarius africanus. The species were completely absent in all other 9 study stations throughout the sampling period. This could be as a result of the shallowness of station 6 and availability of gastropod shells in the station. The phylum Annelida was represented by one Class, the Polychaeta, and two Species Nerieis sp. and Capitella capitata. This class constitute $6 \%$ (32) individuals of the total number of individuals collected during the period of study. Tympanotonus fuscatus Var radula, a species of the Genus Tympanotonus, was also recorded in Station 6 (Lagoon Front) and was also completely absent in all other 9 stations during the study period. Station 6 (Lagoon Front) recorded the highest number of individuals (174) accounting for $34.7 \%$ of the total number of individuals collected during the study period. Station 2 had the least number of individuals (10) accounting for only $1.99 \%$ of the total number of individuals collected during the period of study. The species Tympanotonus fuscatus recorded the highest number of individuals (Table 2) for the study period accounting for $64.5 \%$ of the individuals collected while the species Tympanotonus fuscatus var radula and Iphigenia truncate recorded the lowest number of individuals ( 3 individuals each) accounting for $0.59 \%$ each of the individuals collected during the study period. The highest number of individuals (168) was collected in July 2019 while the lowest number of individuals (96) were collected in the month of August. This could be as a result of the stability of the Lagoon flow and higher transparency due to low rainfall (Nkwoji et al., 2019).

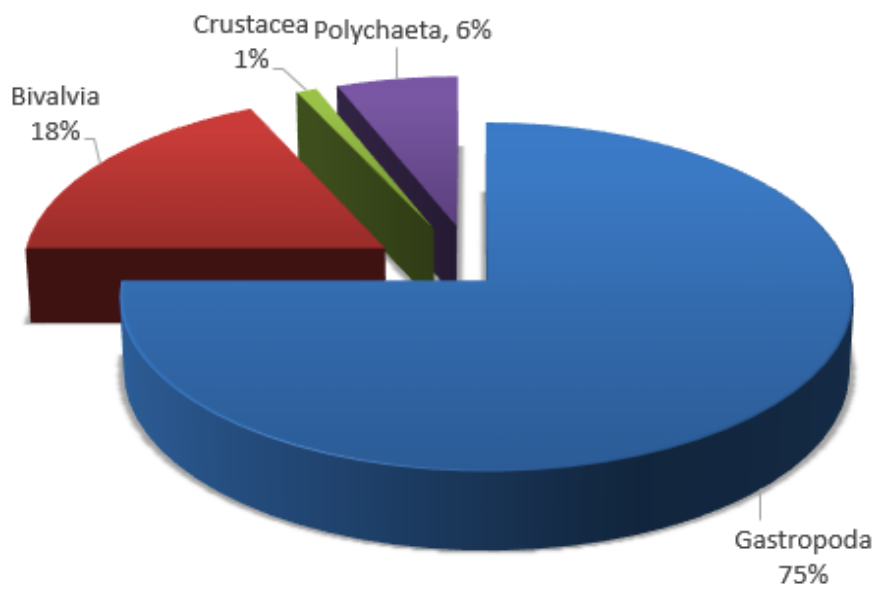

Fig 3. Percentage Class contribution in the total benthic macroinvertebrates for the period of study

Studies on the pollution tolerant nature of Tympanotonus fuscatus have been documented. (Kouadio et al, 2008; Kouadio et al, 2011, Nkwoji et $a l$, 2016). On the other hand, the gastropod Pachymelania aurita, a less tolerant species (Nkwoji et al, 2010 ) was only recorded in 2 (Lagoon Front, and
Abule Eledu) out of the 10 sampling stations. The absence of this species in all other stations and its relatively high abundance in Station 6 and 7 (relatively unpolluted sites) is an indication to its sensitivity to pollution in consonance with the previous observation.. Nkwoji et al $(2010,2016)$ identified the 
polychaetes as tolerant to pollution of the coastal waters. Station 6 (Lagoon Front) recorded the highest number of individuals (174), and this constituted $34.7 \%$ of all individuals sampled during the study. The station also recorded the highest fauna diversity and richness indices indicating the relatively unperturbed nature of the station. This could be attributed to the fact that the station experience less anthropogenic stress compared to the others. The species Tympanotonus fuscatus Var radula was collected in Station 6 (Lagoon Front). This is in consonance with Rosemary et al (2008) who stated that the species inhabit the mudflats of the mangrove swamps at the edges of the Lagos Lagoon. The species occurs naturally in waters with very low salinities between June and November and have a large seasonal fluctuation (Rosemary et al., 2008).

Conclusion: The different pollution sources have impacted negatively on the water chemistry and sediment composition of the lagoon and hence, reduced the diversity and abundance of its benthic macroinvertebrates community. The sedentary nature of this group of benthic fauna is the major reason why they are most impacted. A combined system for water quality monitoring that integrates both physicochemical analysis and biological assessment would be more effective for the evaluation of environmental degradation..

\section{REFERENCES}

Abowei, JF; Sikoki, TM. (2005). Assessment of Heavy Metals Pollution in Soils and Vegetation around Selected Industries in Lagos State, Nigeria. $J$. Geosci. Environ. Protect. 3(1):11-19

Adeyemo, OK, Adedokun, OA, Yusuf, RK; Adeleye, EA. (2008). Sesonl changes in physico-chemical parameters and nutrient load of river sediments in Ibadan City, Nigeria. Global NEST Journal. 10(3): 326-336.

Ajao, EA; Fagade, SO. (1991).Study of the sediments and communities in Lagos Lagoon, Nigeria. Oil and Chem. Pollute. 7:75-117

APHA. (American Public Health Association). (2002), in: Standard Methods for the Examination of Water and Waste Water, 22nd ed., APHA, New York. 1475pp ISBN: 9780875532875.

Ayoade, AA. Fagade, SO; Adebisi, AA.(2006). Dynamics of limnological features of two manmade lakes in relation to fish production. Afr. $J$. Biotech. 5 (10). 1013-1021.
Bulling, MT., Hicks, N., Murray, L., Paterson, DM, Raffaelli, D., White, PC; Solan, M. (2010). Marine Biodiversity-ecosystem functions under uncertain environmental futures.Philosophical Transactions of the Royal Society B: Biol. Sci. 365(1549): 21107-2116.

Christensen, MR., Graham, RD. Vinebrooke, DL. Findlay, MJ; Turner MA (2006). Multiple anthropogenic stressors cause ecological surprises in boreal lakes. Global Change Biology 12(1):2316-2322

Crain, CM, Kroeker, K., and Halpern, BS. (2008). Interactive and cumulative effects of multiple human stressors in marine systems. Ecology letters. 11(12): 1304-1315.

Edokpayi, C.A, and Nkwoji, J.A. (2007). Annual changes in the Physico-chemical and Macrobenthic invertebrate characteristics of the Lagos lagoon sewage dump site at the Iddo Southern Nigeria. Ecology Environ. Conserve 13(1):13-18.

Halpern, BS, Selkoe, KA, Micheli, F, Kappel, CV. (2007). Evaluating and ranking the vulnerability of global marine ecosystems to anthropogenic threats. Conserve. Biol. 21 (5):1301-1315.

Kennish, MJ. (2002). Environmental threats and environmental future of estuaries. Environ. Conserve. 29(1):78-107.

Kouadio KN. Diomandé D., Koné YJ., Bony, KY. Ouattara A. Gourène G., (2011). Distribution of benthic macroinvertebrate communities in relation to environmental factors in the Ebrié Lagoon (Ivory Coast, West Africa). Vie et milieu-life. Environ. 61(2): 59-69.

Kouadio KN., Diomandé D., Ouattara A., Koné YJ., Gourène G. (2008). Taxonomic diversity and structure of benthic macroinvertebrates in Aby lagoon (Ivory Coast, West Africa). Pakistan J. Biol. Sci. 11(18): 2224-2230.

Nkwoji, JA. (2017). The Impacts of Organic Pollution on the Hydrochemistry and Community Structure of Benthic Macrofauna of Lagos Lagoon, Southwest Nigeria. J. Appl. Sci. Environ. Manage. 21 (2) 225-23.

Nkwoji, JA, Awodeyi, SI. (2018). Impacts of sediment mining on the hydrochemistry and macrozoobenthos community in a coastal 
lagoon, Lagos, Nigeria. Arch. Agric. Environ. Sci. 3 (3) 209-215.

Nkwoji, JA; Edokpayi, CA. (2013). Hydrochemistry and community structure of benthic macroinvertebrates of a south western Lagoon, Lagos, Nigeria. Res. J. Pharma. Biol. Chem. Sci. 4(1): $1119-1131$.

Nkwoji, JA, Ugbana, SI, Ina-Salwany, MY. (2019). Impacts of Land based pollutants on Water Chemistry and Benthic Macroinvertebrates community in a coastal Lagoon, Lagos, Nigeria. Sci. Afr. J. 7(1):2020.

Nkwoji, JA, Yakub, A., Ajani, GE, Balogun, KJ, Renner, KO, Igbo, JK, Ariyo, AA, and Bello, BO. (2010). Seasonal Variation in the Water Chemistry and Benthic Macroinvertebrates of a South Western Lagoon, Lagos, Nigeria. J. Am. Sci. 6(3): 85-92.

Nkwoji, JA, Yakub, A., Abiodun, AO; Bello, BO. (2016). Hydrochemistry and Community Structure of Benthic macroinvertebrates in Ilaje coastal waters, Ondo State, Nigeria. Regional Stud. Marine Sci. 8(1):7-13

Ogbeibu, AE. (2005). Biostatistics: A practical approach to research and data handling. Mindex Publishing Co. Ltd., Benin, Nigeria. 264pp,
Olapoju, OA, and Edokpayi, CA. (2018) Response of Macrobenthic Invertebrate to Organic Carbon and Particle Size in Lagos Lagoon, Nigeria. AJFAR, 2(1): 1-13.

Onyema, IC, Lawal-Are, AO, Akinremi, TA, Bassey, OB. (2009) Water quality parameters, chlorophyll a and zooplankton of an estuarine creek in Lagos. J. Am. Sci., 5(6): 76 - 94

Okoye, CO., Onwuka, SU, Obiakor, MO. (2010). Pollution surey in the Lagos Lagoon and its environment consequences: a review. Tropical Built Environ. J. 1:41-56

Rosemary, G, Claridge, EM; Roderick, KG. (2008). Biodiversitydynamics in isolated island communities: interaction between natural and human-mediated processes. Mol. Ecol. 17 (1), 45-57.

Saki, YA; Raphaël, NE., Augustin, KK, Paul, EK. (2017). enthic Macroinvertebrates Composition and SpatiotemporalVariation in Relationship with Environmental Parameters in a Coastal Tropical Lagoon. Inter. J. Sci. Res. Method. 7(4): 149-169 